\title{
Second Language Acquisition, WE, and language as a complex adaptive system (CAS)
}

\author{
Diane Larsen-Freeman \\ University of Michigan, USA \\ Correspondence \\ Diane Larsen-Freeman, University of \\ Michigan, 610 E. University Avenue, \\ Ann Arbor, Michigan 48109 USA. \\ Email: dianelf@umich.edu \\ Abstract

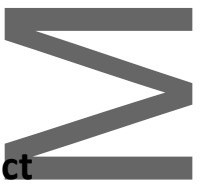

The field of Second Language Acquisition/Development (SLA/D) has evolved to a point where the paradigm gap between SLA and world Englishes (WE), identified by Sridhar and Sridhar (1986), has narrowed. The closing of the gap is due in part to SLA/D and WE leaving behind their ontological inheritance of a static competence from linguistics and finding common ground in a view of language as a complex adaptive system. While differences between the two fields are real and will rightly prevail, there may now exist an opening for a dialogue which can lead to a closing of the gap.

This is the author manuscript accepted for publication and has undergone full peer review but has not been through the copyediting, typesetting, pagination and proofreading process, which may lead to differences between this version and the Version of Record. Please cite this article as doi: 10.1111/weng. 12304 .

This article is protected by copyright. All rights reserved. 


\section{1 | INTRODUCTION}
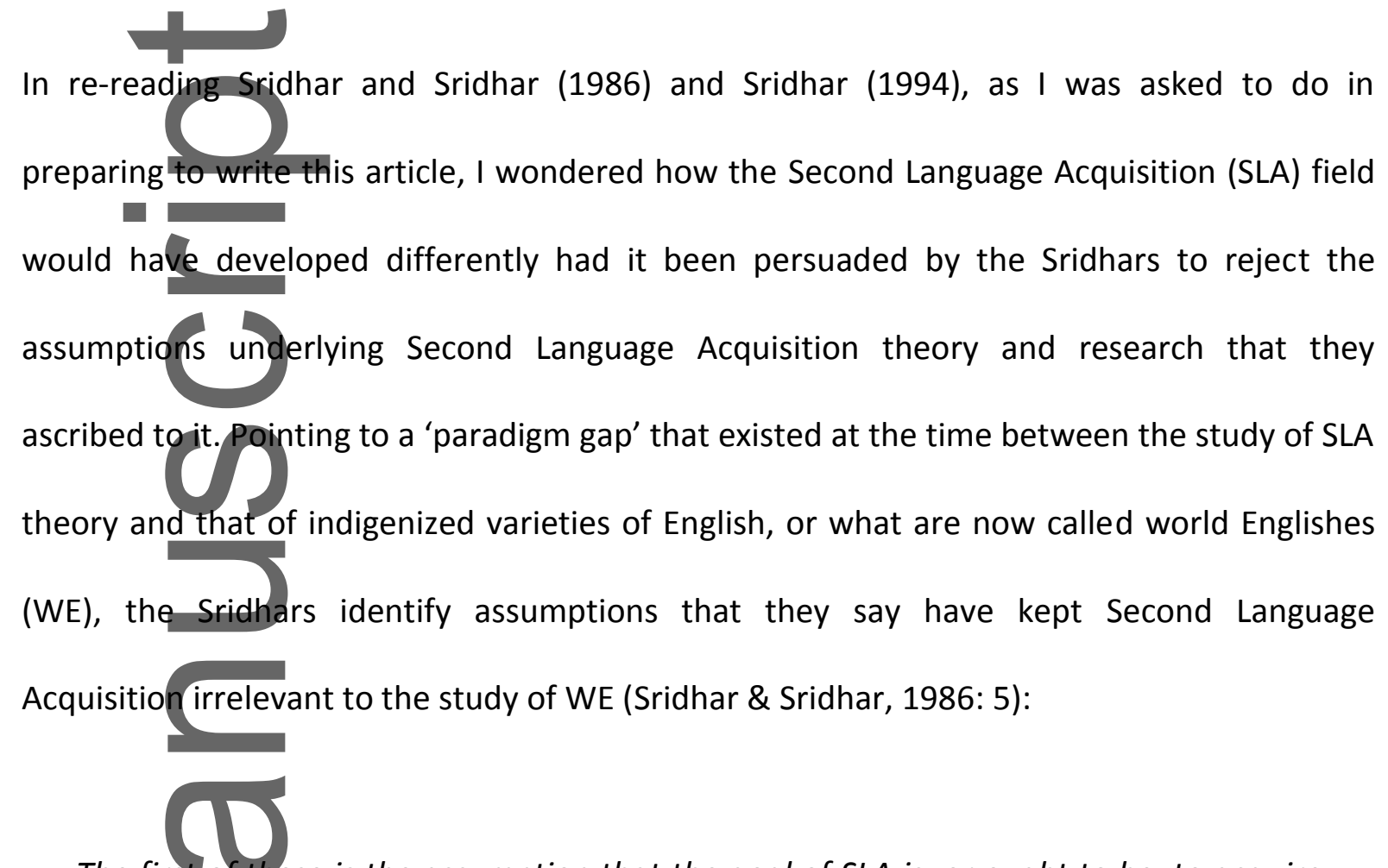

The first of these is the assumption that the goal of SLA is, or ought to be, to acquire native-like competence in the target language (not only in terms of pronunciation and grammatical norms but also in the range of speech acts, styles, and register differentiation) and hence the success of the learner's acquisition is to be judged accordingly.

Embedded in this one statement are three phrases which I highlight in this paraphrase: the goal of hative-like competence, which consists of norms concerning linguistic units, whose mastery is necessary for success. While I cannot say with any certainty that the Sridhars were influential in transforming our understanding, I can say with more assurance that many of these assumptions have been replaced as newer approaches to Second Language Acquisition have come along. These newer approaches have adopted a critical, a social, 
and/or a complexity perspective, all of which have served to expand the psycholinguistic orientation that has been the central focus of mainstream Second Language Acquisition research well into the 1990s. In the present article, I elaborate upon the third newer approach the complexity perspective. It is my intent to apprise readers of this journal of some of the newer trends in Second Language Acquisition, which I believe will facilitate the closing of the gap

In supporting the call to dialogue and synergy that the editors of this volume invite, I aim to make a case for language as a complex adaptive system. I submit that Second Language Acquisition, world Englishes, and English as a lingua franca (ELF) have all presented challenges that have helped advance a complex adaptive system (CAS) view of language. By the same token, Icontend that all three fields of study will benefit from fully embracing this way of understanding language. While this may seem a controversial claim, I am emboldened by the fact that scholars in each of the three fields have begun to recognize a CAS view as a sociocognitive construct, offering important theoretical insights into their respective fields. I begin by nominating Complex Dynamic Systems Theory (CDST) as a metatheory, one that sponsors an alternative to the way that language has traditionally been conceptualized. I next discuss what such a view holds for SLA, or what I prefer to call SLD (second language development) for reasons that I will make clear. Next, I discuss the inroads that this theory has made so far, however preliminary, not only for second language development, but also for English as a lingua franca and world Englishes. As I follow this plan, I will call attention to the work of others who have come to see language as a CAS. First, though, I set the table with a little background. 


\section{2 | A SHARED INHERITANCE FROM LINGUISTIC AND PSYCHOLINGUISTIC THEORIES AND}

RESEARCH

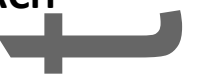

Although the contemporary study of SLD, ELF, and WE has been initiated at different (though not so widely separate) times, the three have formed different scholarly communities, and have had different goals and foci and different paths of development. Second language acquisition researchers study the 'second' language development of individuals, English as a lingua franca researchers investigate the use of English among speakers who do not otherwise share a common language, while world Englishes researchers have focused on the development of varieties of English. However, they are related in their common interest in language and a similar ontological inheritance from linguistics.

Certainly, second language development, I think it is fair to say, has had as its legacy, structuralism, and its successor, generativism. Following their aspiration to represent language as a synchronic system, structuralists specify paradigms of linguistic units such as phonemes, lexemes, and morphemes, which fit into certain positions in a syntagm, such as a sentence. They choose to focus on the abstract system, rather than individuals' linguistic behavior (De Saussure 1916/1959). In a similar fashion, generativists also do not seek to explain the use of language (performance), but rather its underlying system (competence) (Chomsky, 1965). In contrast to structuralism, however, they believe that properties of a generative grammar stem from an innate universal grammar (UG), which is common to all languages. Productive research agendas and useful descriptions of language have followed from these two schools of linguistics. They have motivated a number of language acquisition 
studies, and contributed to language textbooks in the form of paradigms, lists, and rules. An early version of generative grammar, in particular, effected founding assumptions in Second (1)

Language Acquisition in the form of learners' having a 'built-in' internal mental syllabus (Corder, 1967), and along with cognitive psychology, established a field with the proposition that there exists a separate linguistic system, an interlanguage, resulting from learners' attempts to produce the target language (Selinker, 1972), which could be arrayed along a continuum, the endpoint of which is isomorphism with native speaker competence.

WE's linguistic genealogy is different, though similar in some respects. Bolton (2005) points to its origin in the early 1960s when Randolph Quirk and others worked to describe varieties of English from descriptive and historical perspectives. Later, beginning in the 1990s, these attempts were extended through corpus linguistics. Both of these overlap with the 'features-based approach ... which typically involves the linguist in identifying and marking statements about the distinctive features of varieties in terms of pronunciation or 'accent' (phonology), vocabulary (lexis), or grammar (morphology and syntax)' (Bolton, this issue). The study of world Englishes was advanced in the 1970s most notably in the work of Braj Kachry and Larry Smith. Later, the former proposed his influential model of three concentric circles, where each circle represents specific 'types of spread, patterns of acquisition and the functional domains in which English is used across cultures and languages' (Kachru, 1985: 12). However different these starting points for SLA and WE are, one goal that they share is to accurately represent a language system, be it a language variety or a learner's interlanguage. Nevertheless, there are consequences to this worthy pursuit. Describing a language structurally and synchronically requires an assumption of homogeneity and idealization. Codifying a language variety entails stasis-viewing it as a 
product, not a dynamic process. And, even describing a rapidly changing interlanguage fixes it to one point in time. In the same way, UG has its limitations in that it, too, is more appropriate for language representation than development (White, 2003). As such, it does not offer as much to those who wish to investigate phenomena such as language development, or language change over time, or the genesis and evolution of language varieties, or the use of a language as an international lingua franca. A static algorithm cannot account for the continual and never-ending dynamics of language development and use.

While linguists choose to anatomize language into its constituent parts in order to describe it, this approach belies the protean nature of language in development and use (LarsenFreeman \& Freeman, 2008), which is unbounded, not segmented according to linguistic units, and non-teleological, that is, having no end point (Larsen-Freeman, 2006). According to Kretzschman (2015), this same reductionism is practiced by sociolinguists: when they break up language into dialects, they still operate on the assumption that the dialects themselves, however defined, are bounded. An additional consequence of structuralism is the comparison of linguistic systems that it invites. Indeed, contrastive analysis was, and still remains, a respectable scholarly activity. However, the SLA successor to contrastive analysis, error analysis, extended the comparison to that between learner production and native speaker norms, encouraging a deficit view of learner language and research methodologies that perpetuate the comparative fallacy (Bley-Vroman, 1983). Given its origin in the cognitive revolution, the study of learner errors also foregrounded cognitive strategies adopted by language learners, ignoring the social function of language-performance analysis and especially discourse analysis, serving as correctives somewhat later. Informed 
similarly by psycholinguists' search for universals, Second Language Acquisition researchers set aside variation in learner performance in the quest to identify universal acquisition orders and sequences of development. A further limiting practice, arguably necessary from a theoretical linguist's perspective, is the need to remove language from its context of use. However, this move derails any attempts to understand what motivates language learners or users in the choice of language resources they deploy on a given occasion. It also typically segregates language use from any extralinguistic and paralinguistic accompaniments, such as gesture and the expression of affect. Further, it eliminates the contextual scaffolding that affords semantic and pragmatic meaning to any interchange, tacitly endorsing instead the view that meaning resides in the code.

In sum studies of language representation and of language acquisition are complementary. Yet, for some time, most linguists have been consumed by building models of representation, focusing on static competence, and have ignored models of acquisition and use, which focus on dynamic process and performance. It is time to redress the balance (Ellis \& Larsen-Freeman, 2006). If we accomplish this, we may be able to bridge the paradigm gap that concerned the Sridhars, one that Mesthrie and Bhatt (2008) feel still obtains. One other point should be made: whether one practices structuralism, generative linguistics, sociolinguistics or some variety of functionalism, the authority has resided with the linguist, and the resulting descriptions have been etic. What is overlooked, then, is how language is construed by language learners/users. Not only does this oversight disenfranchise language learners/users; it also denies researchers an opportunity to assess their inferences. 
Before moving on, though, it should be acknowledged that the notion of an interlanguage, constructed by cognitively mature learners in a non-random manner, represented a major (

conceptual breakthrough at the time it was proposed. It was a significant departure from the prevaliting behaviorist view where learners' contributions to the acquisition process were virtually ignored. Instead, the major challenge was helping learners overcome the linguistic habits from their other languages, which caused 'interference.' The cognitive revolution, from which SLA descended, was indeed galvanizing. However, time passes and the narrowness of one's way of viewing a particular phenomenon becomes evident. As others have attested (Cook, 1999; May, 2014; Ortega, 2014), it is past time 'to revisit the endpoint of the [interlanguage] continuum' (Larsen-Freeman, 2014), and with it the goal of [explaining] native-like competence, which consists of norms concerning linguistic units, whose mastery is necessary for success.

\section{3 | A NEWER VIEW OF SECOND LANGUAGE DEVELOPMENT}

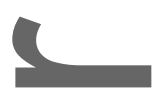

I have been theoretically committed to Complex Dynamic Systems Theory (CDST) for two decades now (Larsen-Freeman, 1997). I am only able to give a brief introduction to it as a metatheory here. 'A metatheory presents a vision of the nature of the world and the objects of that 'World' (Overton, 1998), and I have found the vision CDST inspires apt for a description of language and its learning. CDST is fundamentally a theory of change. As applied to language, it can accommodate process and performance as researchers seek to identify mechanisms of change. 
Language as a process emerges continually through social interaction between speakers (which these days does not have to be face-to-face). As speakers interact (de Bot, Lowie, \& (1)

Verspoor, 2007), higher-level patterns emerge that do not initially appear obvious given the behavior of individual agents in the system (Schoenemann, 2009). Through their interaction, their language resources change. Changes in the speakers' resources are brought about by their alignment with (Atkinson, Churchill, Nishino, \& Okada, 2007), and adaptation to, particular temporal and spatial contexts, including their co-adaptation with other interlocutors (Larsen-Freeman \& Cameron, 2008). In short, language is a 'complex adaptive system' or CAS (Ellis \& Larsen-Freeman, 2009). 'A language is a CAS because of the way it is situated in a social context' (Blythe \& Croft, 2009: 48).

Language performance by learners is also not dependent on an innate module or a static competence, but rather is soft-assembled (Thelen \& Smith, 1994). Learners soft-assemble ( their language resources in order to respond in a meaningful and intentional way to the communicative pressures at hand (Wee, this issue). Each assembly is in response to the idiosyncrasies of the spatial and temporal context. This is a real-time process, taking into account options and constraints, the intrinsic dynamics of the speaker, the individual's language-using history, and the affordances of the context. 'Mind, body, and world thus emerge as equal partners in the construction of robust, flexible behaviors' (Clark, 1997: 45). Learners receive ongoing feedback as they attempt to make meaning in a context. Thus, the natural state of the system can be 'defined as a dynamic adaptedness to a specific context' (Tucker \& Hirsch-Pasek, 1993: 362). Furthermore, when the language resources of the learner changes from one relatively stable attractor state to another, the point of transition is marked with increased behavioral variability, chaos, the result of nonlinearity. 
Having passed through a phase transition, the resources self-organize or restructure, where the new organization may be novel, qualitatively different from earlier organizations (1)

(Larsen-Freeman, 2008). This depiction suggests that we do not view language development as the unfolding of a prearranged plan (Tucker \& Hirsh-Pasek, 1993: 364). Importantly, the meaning-making potential resides with the learner, not with the system of language (Canagarajah, 2013). Thus, rather than considering the development of language from an etic linguist's perspective, a CAS view reframes it from the perspective of the learner. Such a shift has enormous consequences. What is psycholinguistically real language for learners is not identical to what is descriptively real for linguists, and should not be interpreted as such. What is evident in learners' production is their use of meaningful 'chunks,' lexicogrammatical patterns or constructions that frequently occur together and which may be perceived by learners as whole. CDST is centrally concerned with finding patterns in the flux.

The result of this interactivity is that individuals display considerable variability in their development (Verspoor, Lowie, \& van Dijk, 2008). Individual variability should thus not be dismissed as 'bad data' or 'noise' that somehow obscures essential developmental patterns (Clark, 1997: 44). Eskildsen (2012: 365) offers the same explanation for his English learners' variable performance:

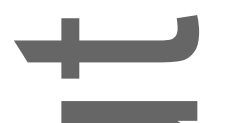

The present research builds on the empirical fact that the patterns in the data display individual acquisitional trajectories; neither targetlike nor nontargetlike features can be generalized to all negated patterns so what the linguist or the analyst calls negation does not seem to be learned as a rule-governed syntactic phenomenon to 
be deployed across diverse linguistic patterns in a broad-sweeping manner, but seems to emerge in different patterns in different ways at different points in time along, rather than across, constructional lines.

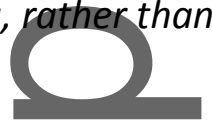

In addition to a social dimension, there is also a cognitive dimension to a CAS. What is perceived and taken in from a CDST perspective has to be initial state dependent-emically controlled Each of us will perceive and categorize, even if only implicitly, certain phenomena while ignoring others. 'At the root of this behavioral flexibility obviously lie highly developed cognitive capacities, which allow us to interiorize part of the complexity of the linguistic system we are immersed into' (Mufwene, Coupé, \& Pellegrino, 2017). We do this by exploiting mechanisms such as analogizing, abduction, statistical preemption, exaptation, relexification, and co-adaptation. 'Crucially, they enable us as speakers to ran anticipate the possible effects of our words on the hearer's mind, and to reconstruct as hearers what was in the speaker's mind when they produced the message we just received' (Mufwene' et al., 2017).

Another influence, although often treated as a separate issue in second language development, is the role of instruction. Some find it unnecessary; others find it highly desirable with older learners, in particular, where their consciousness must be recruited and their attention directed at non-salient forms, such as inflectional morphemes (Ellis, 2005; Larsen-Freeman, 2003). Instruction can exert a powerful influence on language developmental processes. For example, Roehr-Brackin (2014) hypothesizes that the participant she studied used 'top-down processes, based on explicit knowledge [derived from instruction], in combination with L1 transfer, to effectively override the expected 
implicit, bottom-up learning trajectory' (Roehr-Brackin, 2014: 800). In other words, global development emerges from these micro-level local activities in a form of reciprocal or circular causality (Larsen-Freeman \& Cameron, 2008). As Witherington (2011: 66) put it, 'Taking emergence seriously entails a strong commitment to circular causality ... one that recognizes both local-to-global processes of construction and global-to-local processes of constraint.' One other departure from earlier views of Second Language Acquisition (Sridhar, 1994) is the recognition that the monolingual native speaker neither qualifies as the source nor the end point of language learning. What globalization has brought into stark relief is the reality of the world's multilingualism. Where heretofore 'Western societies ... had accepted the monolingualism of the nation state as the "real norm"' (The Douglas Fir Group, 2016: 23), it is now understood that the monolingual native speaker is not a legitimate model for second language learning.

Challenging native-speaker privilege also extends to the right to employ one's language resources to negotiate one's identity (and in so doing to conceivably gaining greater access to the L2) and to manipulate one's languages resources to one's benefit as well, what Kramsch and Whiteside (2008) refer to as 'symbolic competence.' Symbolic competence 'is defined within a complexity theoretical framework as the ability to position oneself advantageously, to be aware of the historicity of words, to reframe and change the context of the interaction' (Kramsch \& Whiteside, 2016). Also, because learners are multilingual, the historical contingency that shapes the way that they use English is affected by the other languages they know. It follows then that multilinguals will be operating from a different base than monalinguals (Jessner, Allgäuer-Hackl, \& Hofer, 2016). Soft assembly and 
historical contingency offer a way of conceptualizing both global and universal changes as well as local, variable, and individual performance (Thelen \& Bates, 2003).

In addition, simplistic accounts of negative transfer have given way to the perception of pervasive crosslinguistic influences. For example, it is now thought that the L1 leads to nonnative conceptual categorization and 'thinking for speaking' (Slobin, 1996). Such

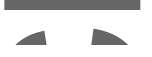

influences are also bidirectional; and they are dynamic and variable, rather than deterministic or constant (Jarvis \& Pavlenko, 2008). Furthermore, from a CDST perspective, U)

learners do not merely transfer or reproduce their linguistic worlds, they actively transform it (Larsen-Freeman, 2013a). It is not as though learners simply 'unload a prior solution from their storehouse of knowledge. [Instead,] [t]hey have crafted it on the spot, adjusting and adapting their prior knowledge in the process' (Carraher \& Schliemann, 2002: 18).

Moreover, a CDST-inspired view of language rejects the notion of language as something is

that is taken in-a static commodity that one acquires and therefore possesses (LarsenFreeman, 2002; Sfard, 1998). Because language is an open, dynamic system, continuously changing, (its potential is always being developed, and it is never fully realized. Thus, 'development' is a better term than 'acquisition' (Larsen-Freeman, 2015) for such a nonteleological process, and one that recognizes that language use cannot be usefully segregated from its ecology (Larsen-Freeman \& Cameron, 2008). As far as the valorization of native speaker mastery is concerned, not all second learners aim to be native-speaker-like. Of course, even if they did, it would not be possible to do so, for among other reasons, there is no homogeneous, static native speaker target; language is an inherently malleable, nonteleological system. Therefore, as I have asserted many times (Larsen-Freeman, 2003), learning a language is not about conformity to uniformity. Thus, learning is not a matter of 
assembling an internal model of an external reality. The fact is that learners extend their linguistic worlds. Achimova (2008) made the observation that children's neologisms should be referred to as an innovation, rather than an error because the children do not know the conventions and simply try to fill in the gaps by creating new forms. This is also true of second language learners, no matter what their age. Indeed, there is no linguistic basis for calling one an error and the other an innovation.

In sum, it is not news at this time to state that consciousness in Second Language Acquisition has evolved to the point where the founding assumptions (and those I cited earlier from Sridhar \& Sridhar, 1986) have been at least challenged, if not abandoned. No longer is it accepted by most researchers that Second Language Acquisition exclusively involves an individual mental process. Similarly, many would not subscribe to there being any endpoint to an interlanguage continuum, let alone one that matches an idealized native speaker competence. And, as for mastery of linguistic units, it is recognized that the units of linguists and how learners perceive the language may not correspond. In any case, the learning process is nonlinear, so mastery, even if learners aspire to it, would be at least difficult to establish, and could only be done through longitudinal investigations. Locating language use and development in the interstices between people and context, rather than within a linguist's system, requires a different approach to thinking about and studying language from that of traditional ones (Ahearn, 2001).

Furthermore, for all their good points, product views of language inevitably seem to invite comparison with an idealized standard, which fuels a discourse of deficiency. In its place, CDST encourages an emic, radically contingent (Cilliers, 2001: 136) process view-one where unique goal-oriented agents are locally focused and intent on making meaning in a 
way that reflects their identity and uses any semiotic resources at hand, including nonverbal ones. Through soft assembly and co-adaptation, learners cobble all available semiotic Through soft

resources together to deal with the exigencies of the moment in a process of bricolage. Moreover, seen in this light, language development is not a separate phenomenon from language Use (as in the case of ELF), or for that matter, language evolution (for instance, world Englishes). They are all happening simultaneously, albeit operating at different timescales and tevels of complexity (Larsen-Freeman \& Cameron, 2008).

I have gone to some length in updating second language development from a CAS perspective with the hope that doing so will be helpful to readers of this journal. I intend to show that the characteristics of second language development, which I have been discussing, atso resonate with ELF and WE, with some allowance for the specific circumstances of each. It is therefore instructive to see how much resonance there is.

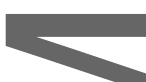

\section{4 | ENGLISH AS A LINGUA FRANCA: A CAS}

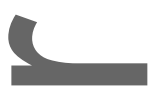

As I have affirmed, language as a complex adaptive system of dynamic usage is radically different from the static system of grammatical principles characteristic of the generativist approach (Beckner, Blythe, Bybee et al., 2009). This position applies to ELF (Larsen-Freeman, 2016a, forthcoming) for as long as there are speakers who use ELF meaningfully through interactions with other ELF users, new properties will emerge, and in contrast to a putative end state grammar, no endpoint will be reached. As Seidlhofer (2011: 88) writes, 'What we see in ELF is indeed the process of language dynamics whereby the language is adapted and altered to suit the changed circumstances of its use.' Thus, while initially ELF research was 
much taken up with describing linguistic features, '[i]n the emergent ELF scholarship, a processual, communicative view is given priority over an emphasis on characteristic linguistic features' (Schneider, 2012: 62).

According to a CAS view of language development, learners' language has the shape that it does because of the way that it is used and adapted, not because of an innate bio-program or internal mental organ (Larsen-Freeman, 2012a: 75). Just as with SLD, Seidlhofer (2011: 99) states quite explicitly: '[ELF] at any point in time is continually transformed by use. They [ELF speakers] draw on ELF as a complex adaptive system.' Joining Seidlhofer in this position are several ELF researchers, among them Baird, Baker, and Kitazawa (2014: 181, 171), who draw explicitly on Complexity Theory 'as a conceptual tool that can be useful in guiding our thinking about the dynamic nature of language.' They underscore 'the importance of viewing language from multiple dimensions in which its contextual embodiment is crucial, and its isolation and compartmentalisation is problematic.'

Also important for ELF, as it is for SLD, is the notion of adaptation to context.

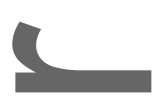

Naturally, adaptation is also a strong theme in the ELF literature. This is to be expected; it would be rather peculiar if speakers developed unique communicative strategies to deal with lingua franca encounters. It seems more plausible that speakers in lingua franca-encounters draw on strategies they have experience of using in other settings, and adapt them to meet the demands of the new context. (Mortensen, 2013: 35)

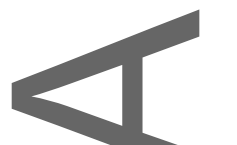

Then, too, just as with SLD, variability is also characteristic of ELF, House (2014: 2) makes it clear that:

This article is protected by copyright. All rights reserved. 
ELF is characterized by great variability; it is NOT a fixed code, and cannot be defined by its formal characteristics ... ELF is negotiated ad hoc, varying according to context, speaker group and communicative purpose. It is individually shaped by its users and can fulfil Many different functions ranging from simple small-talk to sophisticated arguments. While of course based on English, ELF is also full of interlingual and intercultural adaptations, typically containing elements from different linguacultures.

Indeed, Mackenzie (2014: 4) has described ELF interactions as 'likely to include borrowing, code-switching, and other types of crosslinguistic interaction.' Thus, the language resources of individual ELFusers may overlap, but will never be identical, not only because of the users' different language profiles, but also because of their own history of interactions with others and their own needs. These comments are very much in keeping with the SLD literature regarding individual trajectories of development (Eskildsen, 2012).

Also with regard to the contentious issue of native speaker norms, '[t]he appropriation of the language as a lingua franca necessarily focuses attention not on what is proper English in reference to native-speaker norms, but what is appropriate for English for new and different communicative and communal purposes' (Seidlhofer, 2011: 88). In addition, Jenkins (2015) observes because ELF is used in a multilingual context, it is even more difficult to ascertain whether a particular form is an error or an innovation. What appears to be an error from a monolingual English point of view may, in fact, be an innovation from a multilingual one (Larsen-Freeman, 2016b). ELF use is contingent upon the speakers' perception of, and acting on, the affordances present in the context to create meaning, not in their applying a fixed 
set of rules. In fact, instead of applying rules, there is a tendency for speakers to reuse existing forms as much as possible, even if the forms already have other functions. This process of bricolage works in both directions. Since ELF interactions are multilingual, it is possible not only for inventions to surface in English, but also for new forms to be adopted into the contact language. As ELF researcher Mauranen put it (2012: 44), 'Language systems $-1$

influence each other in multilingual cognition, and in addition to this mutual influence, they act like other complex systems in interaction with their environment' (Mauranen, this issue).

\section{5 | WORLD ENGLISHES AS CAS}

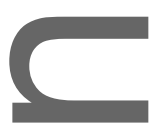

There are clear differences between ELF and WE. It follows then that the disciplines of world Englishes and ELF have been practiced and viewed as largely independent of each other' (Schneider, 2012: 60). A major reason for the independence is 'ELF represents a type of process, a context of use ... and should not be viewed as "a variety"; it is important to recognize (its diversity and interactive character' (Schneider, 2012: 60). Nonetheless, an important question persists as to whether or not a stabilized ELF would lead to endonormativity, eventually becoming another variety of English (MacKenzie, 2014; Schneider, 2012).

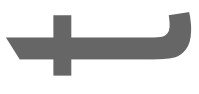

So, perhaps at the expense of restricting the notion of ELF usage somewhat, to specific social settings which remain stable for a longer period of time, I hypothesize that such ELF behavior may be viewed as an early (embryonic?) stage of an 
evolutionary trajectory which may lead to and, in some historical settings, has led to the emergence of [WEs] in the long run. (Schneider, 2012: 87)

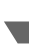

A CAS understanding of language evolution may prove helpful in assessing the claim that Schneider(2012) makes because Schoenemann (2017) advises that:

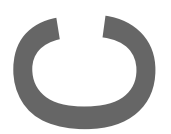

If instead we view language as the result of a complex adaptive system, in which interacting biological and cultural evolutionary systems-each with their own constraints, influences, and partly-interdependent histories-conspire over evolutionary time to produce a system of communication, the problem of language evolution becomes tractable.

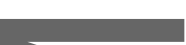

In any case, ELF researcher Jenkins (2009: 201) sensibly clarifies:

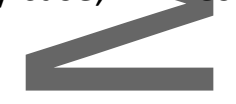

Instead, no matter which [Kachruvian] circle of use we come from, from an ELF perspective we all need to make adjustments to our local English variety for the benefit of our interlocutors when we take part in lingua franca English communication. ELF is thus a question, not of orientation to the norms of a particular group of English speakers, but of mutual negotiation involving efforts and adjustments from all parties. 
At times, then, WE speakers are also ELF users. It seems that this in-time mutual negotiation and accommodation in the service of meaning-making could be said of all three areas, including second language development (Motschenbacher, 2013; Saraceni, 2010).

With regard to WE and SLD, as Mesthrie and Bhatt (2008) succinctly put it, one key difference is the focus: in second language development, it is on acquisition, and in WE on population. It follows then that world Englishes are primarily for use with other speakers of the same variety; hence, the native speaker norm, which has historically applied to second language development, is irrelevant in these contexts (Sridhar, 1994). However, I have already made the point that the field of second language development is attempting to divest itself of reference to native speaker norms. Furthermore, if we focus on a nonnormative process, rather than product, we may recognize similarities between individuals and populations from a CAS perspective.

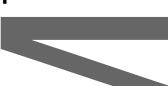

Language exists both in individuals (as idiolect) and in the community of users (as communal language). Language is emergent at these two distinctive but interdependent levels: An idiolect is emergent from an individual's language use through social interactions with other individuals in the communal language, whereas a communal language is emergent as the result of the interaction of the idiolects [...] Both communal language and idiolects are in constant change and reorganization. Languages are in constant flux, and language change is ubiquitous. (Beckner et al., 2009: 14-15). 
Mufwene (2008: 131) agrees: 'Idiolects are "complex adaptive systems".' Extrapolating from idiolects, so too, he contends are communal languages. In their evolution, they reflect selective adaptations undergone by idiolects. Then, too, because they exist by virtue of being spoken by individuals, communal languages are inherently variable. Moreover, speakers of both share the propensity to innovate in 'the adapted language' (Sridhar, 1994). As De Costa and Crowther (this volume) observe 'From the viewpoint of both SLA and WE, language is dynamic, and this occurs both across users, but also within.' With regard to WE, Hilgendorf (2015: 58) comments:

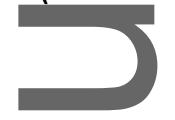

The fact that users of language concurrently are engaged in changing the code they are using speaks to the inherent dynamic nature of language use. The users of language, within their groups of interaction, to varying degrees continually adapt and change the code they use.

Schneider (1997) was, I believe, the first WE researcher recognize the potential for CDST (or the related chaos theory he draws on) to provide this way of thinking about world Englishes. He has argued more recently (2015) that whereas WE research has tended to focus on the features of individual varieties, as measured against some external yardstick, it behooves WE researchers to attempt to understand world Englishes as 'complex dynamic (or "adaptive") systems.' Such a theoretical perspective, 'constitutes an enriching framework to enhance our understanding of the emergence of world Englishes as well, in addition to crediting to them the status of distinctive, independent and complex entities' (Schneider, 2015). 
To cite just one example of how adopting this theoretical perspective potentially helps to bridge the paradigm gap, Mufwene et al. (2017) underscore the fact that 'since speakers' the

natural and socioeconomic ecologies constantly change, as do their communication needs, a language always has to adapt to these changes.' One of the ways that this is accomplished both at idiolectal level and at the communal level is through exaptation, a strategy I mentioned in conjunction with my discussion of second language development earlier. Steels and Buehls (2017: 32) observe:

If a new invention is based on the exaptation of an existing word or construction in a slightly different context, then there is a higher chance that the hearer might guess this new meaning than if a radically new invention is made. Hence the exapted invention has a higher chance to propagate and survive in the communal language (2) and it contributes to keeping the language inventory in check.

Other areas of overlap between SLD and WE may include the 'transfer-induced' features of WE varieties (Kortmann, Burridge, Mesthrie, Schneider, \& Upton, 2004) and a nonteleological orientation, as least in terms of goal-directedness (Mukherjee, 2007). There are likely other correspondences as well. The point is that now may be the time to explore the interfaces between WE and SLD. Indeed, some have already engaged in doing so (Mukherjee \& Hundt, 2011; Nesselhauf, 2009).

There is always a risk, of course, of generalizing processes across different contexts of use. I recognize that my cursory treatment might leave some unconvinced of the parallels across the different areas. Nevertheless, I concur with Seidlhofer (2009: 243) who maintains: 
ELF and postcolonial Englishes are very different realities on the ground. But this does not mean that the different perspectives cannot be drawn on fruitfully and combine forces where appropriate. It seems to me, for instance, that Schneider's evolutionary perspective is of relevance to all contexts, emphasizing as it does the notion of linguistic ecologies and the assumption that 'speakers keep redefining and expressing their linguistic and social identities, constantly aligning themselves with other individuals and thereby accommodating their speech behaviour to those they wish to associate and be associated with' (Schneider 2007: 21).

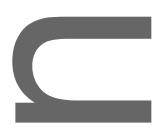

I have written this article for a WE audience with the goal of demonstrating that second language development has moved in a direction whereby the gap between the two areas might be bridged. However, a bridge is not one-way. Second language development researchers have something to learn from world Englishes researchers as well. For instance, Mufwene((2008: 153) suggests that Second Language Acquisition researchers might learn more about markedness from language varieties. The issue of markedness is certainly relevant in SLD, in, for example, the 'Markedness Differential Hypothesis' (Eckman, 1977). In addition, perhaps the typical multilingualism of ELF and WE can be instructive for second language development in its continuing effort to shed its monolingual bias (May, 2014; Ortega, 2014), stemming from its historical development in 'predominantly monolingual Western countries' (Sridhar, 1994: 803). I am sure that there are many more lessons to be learned than these two examples would indicate. 


\section{6 | CONCLUSION}

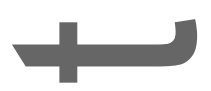

In this article, thave outlined some directions that the second language development field has taken. Not all second language development researchers would subscribe to this account, of course. Some would endorse a different narrative. Furthermore, I have discussed only few of the ramifications of the move to complexity. For example, I have said nothing about the enhanced agency ascribed to the learner/user that accompanies a CAS account. Then, too, nothing has been said about pedagogical recommendations, such as teaching grammar as a process, what I have called 'grammaring', rather than a product, and teaching earners to adapt their language resources to changing circumstances (LarsenFreeman, 2013b). I have also spent no time on a critical perspective, which CDST characterizes as 'the logic of freedom' replacing the 'logic of determinism' (Osberg, 2008). reles Nevertheless, I would submit that the three assumptions that the Sridhars identified, with which 1 began this article, no longer hold. Language learning is not about some linear progression of monolinguals from one homogeneous language community to another. It is not about the linear aggregation of linguistic units, and success is not measured by a learner's conformity to a static native speaker competence. For these reasons, I believe that the paradigm gap between WE and SLA that the Sridhars pointed to thirty years ago has at least narrowed.

It is perhaps not so surprising that I have adopted this position because 'general complexity' (Morin, 2007) discourages the practice of dichotomizing exclusively, that is, SLD versus WE, instead practicing a convergent heuristic, looking for what connects as well as what distinguishes (Morin, 2007). Still, I think that the convergence that I perceive with SLD, 
ELF, and WE is neither illusory nor out of step with modern times. Indeed, it should not be surprising in this era of transdisciplinarity (Larsen-Freeman, 2012b; The Douglas Fir Group, 2016) that the search for what connects should be at least on equal footing to that for distinctiveness.

'[I]ntercultural English is used on a global scale, it is high time for us to try and find more appropriate theoretical tools to come to grips with this fact' (Hülmbauer, 2009: 69). I think such theoretical tools lie with a view of language, its learning, and its use-a view informed by CDST as a metatheory (Larsen-Freeman, 2017). The way of thinking that CDST inspires is promising for dealing with both the stability and the flux of language use and development. It is

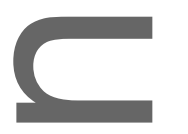

[L]argely inspired by the complex means through which nature regenerates and resty maintains order under constantly changing conditions ... general complexity realizes that complex systems are constantly negotiating a fine line between being robustly structured whilst at the same time being open to the constant possibility of change and adaptation. (Human, 2015: 7)

I am neither advocating nor predicting that what would result from adopting a CAS view is a meshing of different fields and a complete closing of the paradigm gap. Indeed, I have pointed out the distinctiveness among them as well as the resonances. Instead, I am putting forth the position that there are commonalities that were not visible in the past, and that recognizing these might lead to opening a dialogue. A theory, such as CDST, can be useful in providing SLD, ELF, and WE researchers with discourse for connecting with others who are 
thinking about and studying language development and use. And, finally, it is not contradictory to say that opening a dialogue may bring about the closing of a gap.

REFERENCES

口

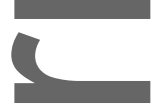

Achimova, A. (2008). Verb innovations in spontaneous speech of children. In T. Marinis, A. Papangeli \& V. Stojanovik (Eds.), Proceedings of the child language seminar 2007 - 30th anniversary (pp. 4-14). Reading: University of Reading.

Ahearn, L.(2001) Language and agency. Annual Review of Anthropology, 30, 109-137.

Atkinson, D., Churchill, E., Nishino, T., \& Okada, H. (2007). Alignment and interaction in a sociocognitive approach to second language acquisition. The Modern Language Journal, 91(2), 169-188.

Baird, R., Baken, W., \& Kitazawa, M. (2014). The complexity of ELF. Journal of English as a Lingua Franca, 3(1), 171-196.

Beckner, C., Blythe, R., Bybee, J., Christiansen, M., Croft, W., Ellis, N. C., ... Schonemann, T. (2009) Language is a complex adaptive system: Position paper. Language Learning, 59(1), 1-26.

Bley-Vroman, R. (1983). The Comparative fallacy in interlanguage studies: The case of systematicity. Language Learning, 33(1), 1-17.

Blythe, R., \& Croft, W. (2009). The speech community in evolutionary language dynamics. Language Learning special issue, 59(1), 47-63.

Bolton, K. (2005). Symposium on World Englishes Today (Part II): Where WE stands: approaches, issues, and debate in world Englishes. World Englishes, 24(1), 69-83. 
Canagarajah, S. (2013). Translingual practice: Global Englishes and cosmopolitan relations. New York: Routledge.

Carraher, D. W., \& Schliemann, A. (2002). The transfer dilemma. Journal of the Learning Sciences, 11, 1-24.

Chomsky, N. (1965). Syntactic structures. The Hague: Mouton de Gruyter.

Cilliers: (2001). Boundaries, hierarchies and networks in complex systems. International Journal of Innovation Management, 5(2), 135-147.

Clark, A. (1997). Being there: Putting brain, body, and world together again. Cambridge, MA: The MIT Press.

Cook, V. (1999). Going beyond the native speaker in language teaching. TESOL Quarterly, 33(2), 185-209.

Corder, S. P. (1967). The significance of learners' errors. International Review of Applied Linguistics, 5, 161-170.

De Bot, K., Verspoor, M., \& Lowie, W. (2007). A dynamic systems theory approach to second language acquisition. Bilingualism: Language and Cognition, 10(1), 7-21.

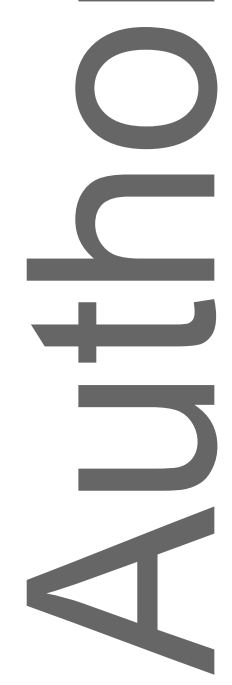


De Saussure, F. 1916/1959. Cours de linguistique générale. In C. Bailly \& A. Sechehaye (Eds.) (translated by W. Baskin in 1959 as Course in General Linguistics). New York: $\checkmark$

Philosophical Library.

Eckman, F. (1977). Markedness and the contrastive analysis hypothesis. Language Learning, $27(2), 315-330$.

Ellis, N. C. (2005). At the interface: Dynamic interactions of explicit and implicit language knowledge. Studies in Second Language Acquisition, 27(2), 305-352.

Ellis, N. C., \& D. Larsen-Freeman. (2006). Language emergence: Implications for applied linguistics-Introduction to the special issue. Applied Linguistics, 27(4), 558-589.

Ellis, N. C., \& D. Larsen-Freeman (Eds.). (2009). Language as a complex adaptive system. Boston, MA: Wiley-Blackwell.

Eskildsen, S. (2012). L2 negation constructions at work. Language Learning, 62(2), 335-372. (n)

Hilgendorf, S. K. (2015). Plurality and world Englishes: The social realities of language use. World Englishes, 34(1), 55-67.

House, J. (2014). English as a global lingua franca: A threat to multilingual communication and translation? Language Teaching, 47(3), 363-376.

Hülmbauer, C. (2009). We don't take the right way: We just take the way that we think you will understand: The shifting relationship of correctness and effectiveness in ELF communication. In A. Mauranen \& E. Ranta (Eds.), English as a lingua franca: Studies and findings (pp.323-347). Newcastle upon Tyne: Cambridge Scholars.

Human, O. (2015). Complexity: E-Special introduction. Theory, Culture \& Society, 3, 1-20. Jarvis, S., \& Pavlenko, A. (2008). Crosslinguistic influence in language and cognition. New York: Routledge. 
Jenkins, J. (2009). English as a lingua franca: Interpretations and attitudes. World Englishes, 28(2), 200-207.

Jenkins, J. (2015). Repositioning English and multilingualism in English as a lingua franca. Englishes in Practice, 2, 49-85.

Jessner, U., Allgäuer-Hackl, E., \& Hofer, B. (2016). Emerging multilingual awareness in educational contexts: From theory to practice. The Canadian Modern Language Review/La Revue canadienne des langues vivantes, 72(2), 157-182.

Kachru, B. (1985). Standards, codification and sociolinguistic realism: The English language in the Outer Circle. In R. Quirk \& H. Widdowson (Eds.), English in the world: Teaching and learning the language and literatures (pp. 11-30). Cambridge: Cambridge University Press.

Kortmann, B, Burridge, K., Mesthrie, R., Schneider, E. W., \& Upton, C. (Eds.). 2004. A handbook of varieties of English, vol. 2: Morphology and syntax. Berlin: Mouton de Gruyter.

Kramsch, C., \& Whiteside, A. (2008). Language ecology in multilingual settings: Towards a theory of symbolic competence. Applied Linguistics, 29(4), 645-671.

Kramsch, C., \& Whiteside, A. (2016). Annotated bibliography on symbolic competence. A presentation at the University of Arizona, February 26.

Kretzschmar, W. (2015). Language and complex systems. Cambridge: Cambridge University Press. Larsen-Freeman, D. (1997). Chaos/complexity science and second language acquisition. Applied Linguistics, 18, 141-165. 
Larsen-Freeman, D. (2002). Language acquisition and language use from a chaos/complexity perspective. In C. Kramsch (Ed.), Language acquisition and language socialization (pp. 33-46) London: Continuum.

Larsen-Freeman, D. (2003). Teaching language: From grammar to grammaring. Boston, MA: Heinle/Cengage.

Larsen-Freeman, D. (2006). Second language acquisition and the issue of fossilization: There is no end and there is no state. In Z. H. Han \& T. Odlin (Eds.), Studies of fossilization in second language acquisition (pp. 189-200). Bristol: Multilingual Matters.

Larsen-Freeman, D. (2008). On the need for a new understanding of language and its development. Journal of Applied Linguistics, 3(3), 281-304.

Larsen-Freeman, D. (2012a). Complexity theory. In S. Gass \& A. Mackey (Eds.), Handbook of second Yanguage acquisition (pp. 73-87). London: Routledge.

Larsen-Freeman, D. (2012b). Complex, dynamic systems: A new transdisciplinary theme for applied linguistics? Language Teaching, 45(2), 202-214.

Larsen-Freeman, D. (2013a). Transfer of learning transformed. Language Learning special issue, $63,107-129$.

Larsen-Freeman, D. (2013b). Complex, dynamic systems and technemes. In J. A. Morgan \& T. Murphey (Eds.), Meaningful action: Earl Stevick's influence on language teaching (pp. 190-201). Cambridge: Cambridge University Press.

Larsen-Freeman, D. (2014). Another step to be taken: Rethinking that endpoint of the interlanguage continuum. In Z.-H. Han \& E. Tarone (Eds.), Interlanguage: Forty years later (pp. 203-220). Amsterdam: John Benjamins. 
Larsen-Freeman, D. (2015). Saying what we mean: Making a case for 'language acquisition' to become 'language development.' Language Teaching, 48(4), 491-505.

Larsen-Freeman, D. (2016a). A successful union: Linking ELF with CAS. In L. Lopriore \& E.

Grazzi (Eds.), Intercultural communication: New perspectives from ELF (pp. 15-29).

Rome: Roma Tres Press.

Larsen-Freeman, D. (2016b). Complexity theory and ELF: A matter of teleology. In M.-L. Pitzl

\& R. Osimk-Teasdale (Eds.), English as a lingua franca: Perspectives and prospects,

Contributions in honor of Barbara Seidlhofer (pp. 139-145). Berlin: Mouton De Gruyter.

Larsen-Freeman, D. (2017). Complexity theory: The lessons continue. In L. Ortega \& Z. H.

Han (Eds.), Complexity theory and language development: In celebration of Diane Larsen-

Freeman. Amsterdam: John Benjamins.

Larsen-Freeman, D. (Forthcoming). Complexity and ELF. In J. Jenkins, W. Baker \& M. Dewey

(Eds.), The Routledge handbook of English as a lingua franca. Abingdon: Routledge.

Larsen-Freeman, D., \& Freeman, D. (2008). Language moves: The place of 'foreign'

languages in classroom teaching and learning. Review of Research in Education, 32, 147-

186.

MacKenzie, 1. (2014). English as a lingua franca: Theorizing and teaching English. New York:

\section{Routledge}

Mauranen, A. (2012). Exploring ELF: Academic English shaped by non-native speakers.

Cambridge: Cambridge University Press.

May, S. (2014). Disciplinary divides, knowledge construction, and the multilingual turn. In S.

May (ed.), The multilingual turn: Implications for SLA, TESOL and bilingual education (pp.

7-31). New York: Routledge.

This article is protected by copyright. All rights reserved. 
Mesthrie, R., \& Bhatt, R. M. (2008). World Englishes: The study of new linguistic varieties.

Cambridge: Cambridge University Press.

Morin, E. (2007). Restricted complexity, general complexity. In C. Gershenson, D. Aerts \& B. Edmonds (Eds.), Worldviews, science and us: Philosophy and complexity (pp. 5-29).

Singapore: World Scientific.

Mortensen, J. (2013). Notes on English used as a lingua franca as an object of study. Journal of English as a Lingua Franca, 2, 25-46.

Motschenbacher, H. (2013). New perspectives on English as a European lingua franca.

Amsterdam:John Benjamins.

Mufwene, S. S. (2008). Language evolution: Contact, competition and change. London:

Continutrin

Mufwene, S. S., Coupé, S., \& Pellegrino, F. (2017). Complexity in language: A multifaceted (2)

phenomenon. In S. Mufwene, C. Coupé \& F. Pellegrino (Eds.), Complexity in language:

Developmental and evolutionary perspectives. Cambridge: Cambridge University Press.

Mukherjee, J. (2007). Steady states in the evolution of New Englishes: Present-day Indian

English as an equilibrium. Journal of English Linguistics, 35(2), 157-187.

Mukherjee, J., \& Hundt, M. (2011). Exploring second-language varieties of English and learner Englishes: Bridging the paradigm gap. Amsterdam: John Benjamins.

Nesselhauf, N. (2009). Co-selection phenomena across New Englishes: Parallels (and differences) to foreign learner varieties. English World-Wide, 30(1), 1-26.

Ortega, L. (2014). Ways forward for a bi/multilingual turn in SLA. In S. May (Ed.), The multilingual turn: Implications for SLA, TESOL and bilingual education (pp. 32-52). New York: Routledge. 
Osberg, D. C. (2008). The logic of emergence: An alternative conceptual space for theorizing critical education. Journal of the Canadian Association for Curriculum Studies, 6(1), 133161.

Overton, W. F. (1998). Metatheory and methodology in developmental psychology. Retrieved from https://astro.temple.edu/ overton/metatheory.html

Roehr-Brackin, K. (2014). Explicit knowledge and processes from a usage-based perspective: The developmental trajectory of an instructed L2 learner. Language Learning, 64(4), 771-808.

Saraceni, M. (2010). The relocation of English: Shifting paradigms in a global era. Basingstoke: Palgrave Macmillan.

Schneider, E. W. (1997). Chaos theory as a model for dialect variability and change? In A. R. Thomas (Ed.), Issues and methods in dialectology (pp. 22-36). Bangor: Department of (n)

Linguistics, University of Wales.

Schneider, E. W. (2012). Exploring the interface between world Englishes and second language acquisition - and implications for English as a lingua franca. Journal of English as a Lingua Franca, 1(1), 57-91.

Schneider, E. W. (2015). Conference abstract. Changing English, University of Helsinki, June 2015

Schoenemann, T. (2009). Evolution of brain and language. Language Learning special issue, 59(1), 162-186.

Schoenemann, T. (2017). A complex-adaptive-systems approach to the evolution of language and the brain. In S. S. Mufwene, C. Coupé \& F. Pellegrino (Eds.), Complexity in 
language: Developmental and evolutionary perspectives. Cambridge: Cambridge University Press.

Seidlhofer, B. (2009). Common ground and different realities: World Englishes and English as a lingura franca. World Englishes, 28(2), 236-245.

Seidlhofer, B. (2011). Understanding English as a lingua franca. Oxford: Oxford University Press.

Selinker, L (1972). Interlanguage. International Review of Applied Linguistics, 10, 219-231.

Sfard, A. (1998). On two metaphors for learning and the dangers of choosing just one. Educational Researcher, 27, 4-13.

Slobin, D. (1996). From 'thought and language' to 'thinking for speaking.' In J. J. Gumperz \& S. C. Levinson (Eds.), Rethinking linguistic relativity (pp. 70-96). New York: Cambridge University Press.

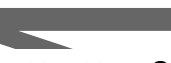

Sridhar, K. K., \& Sridhar, S. N. (1986). Bridging the paradigm gap: Second language acquisition theory and indigenized varieties of English. World Englishes, 5(1), 3-14.

Sridhar, S. N. (1994). A reality check for SLA theories. TESOL Quarterly, 28(4), 800-805.

Steels, L., \& Beuls, K. (2017). How to explain the origins of complexity in language: A case study for agreement systems. In S. S. Mufwene, C. Coupé \& F. Pellegrino (Eds.), Complexity in language: Developmental and evolutionary perspectives. Cambridge: Cambridge University Press.

The Douglas Fir Group. (2016). A transdisciplinary framework for SLA in a multilingual world. The Modern Language Journal, 100(1), 19-47.

Thelen, E., \& Bates, E. (2003). Connectionism and dynamic systems: Are they really different? Developmental Science, 6, 378-391. 
Thelen, E., \& Smith, L. (1994). A dynamic systems approach to the development of cognition and action. Cambridge, MA: The MIT Press.

Tucker, M., \& Hirsch-Pasek, K. (1993). Systems and language: Implications for acquisition. In L. Smith \& E. Thelen (Eds.), A dynamic systems approach to development: Applications (pp. 359-384). Cambridge, MA: The MIT Press.

Verspoor, M., Lowie, W., \& van Dijk, M. (2008). Variability in L2 development from a dynamic systems perspective. The Modern Language Journal, 92(2), 214-231.

White, L. (2003). Second language acquisition and universal grammar. Cambridge: Cambridge University Press.

Witherington, D. C. (2011). Taking emergence seriously: The centrality of circular causality for dynamic systems approaches to development. Human Development, 54, 66-92. 